\title{
THE RESPONSE OF PESANTREN COMMUNITY IN MAGELANG TO THE IMPLEMENTATION OF MEASLES RUBELLA VACCINATION
}

\author{
Mahsun \\ Universitas Islam Negeri Walisongo Semarang \\ Ngaliyan, Semarang, Central Java, Indonesia \\ E-mail:mahsun@walisongo.ac.id \\ Junaidi Abdillah \\ Universitas Islam Negeri Walisongo Semarang \\ Ngaliyan, Semarang, Central Java, Indonesia \\ E-mail:mahsun@walisongo.ac.id \\ Ahmad Munji \\ Marmara Üniversitesi İstanbul Turki \\ Egitim, Fahrettin Kerim Golay, Istanbul, Turkey \\ E-mail:amunji87@yahoo.co.id
}

\begin{tabular}{c|c|c}
\hline Received: & Revised: & Approved: \\
$01 / 09 / 2021$ & $14 / 12 / 2021$ & $14 / 12 / 2021$ \\
\hline
\end{tabular}

DOI : 10.32332/akademika.v26i2.3627

\begin{abstract}
This research is motivated by the pros and cons of the Measles Rubella vaccination program among Islamic boarding schools in Magelang, Indonesia. The aim was to find out the response of the Pesantren community in Magelang, Indonesia as a representative of the Muslim community to the Measles Rubella (MR) vaccination law in 2017. Moreover, this paper was focused on the investigation for the elements that is influencing the emergence of pros and cons attitudes among the Pesantren community and interfaith communities in Magelang, Indonesia toward the MR vaccination law. The scope of the study is to analyze the opinion of the ulama holding the Pesantren and interfaith communities about the law of MR vaccination. The author used a sociology approach. Data obtained through observation, interview and literature study. The author used deductive-inductive methods and critical reflection to analyze the data. The article presents the conclusion of research that the Pesantren communityresponse in Magelang to inplementation of vaccination occurred pros and cons. Groups who reject vaccination argue that vaccination is against religious law. Meanwhile, the group receiving vaccination argues that it is important and emergencies in ensuring the health of children to avoid the disease that will result from not being immunized. So is the perspective of world religions. Essentially Islam, Protestant, Hindu received vaccination as an effort to ensure the health of children. While Catholics and Buddhism tend to reject vaccination.
\end{abstract}

Keywords: Response, pesantren , interfaith communities, and vaccination 


\section{A. Introduction}

Pesantren play a large role and influence in terms of shaping the character of society. Therefore Pesantren as an educational institution that is concerned in the religious field must be responsive and adaptive to changes in the situation and conditions that surround them, including government policies. One of the government's policies is the Measles Rubella (MR) vaccination program which is carried out in two phases, namely in 2017 in Java and in 2018 outside of Java. ${ }^{1}$

Pesantren or Islamic boarding school is one of the social institutions in Indonesia. As a social institution, Pesantren have contributed for centuries to participate in educating human life. The core values taught in the Pesantren include sincerity, simplicity, independence, solidarity and self-control. Santri is a person who is housed in a boarding school consisting of young men and women. They are separated from their families, so they are able to contribute to a sense of individual commitment to faith and close ties with a teacher. ${ }^{2}$

The vaccination policy has, in reality, generated mixed responses among Pesantren communities. That is due to the problem of some of the Pesantren community's doubts about the halal vaccine being injected into the body of the immunized child. Therefore the Indonesian Ulama Council (MUI) issued fatwa number 4 of 2016 concerning the halal vaccine for the benefit of vaccination for reasons of emergency or intent to occupy an emergency position as long as no vaccine has been found that is free from pork enzymes.

The Pesantren community in Magelang, which is part of the Pesantren community in Indonesia, should be able to accept and implement the government's policy because it has received vaccine guarantees from the MUI. But the reality is that there are still Islamic Boarding School caretakers in Magelang who refused their students to be given MR vaccination in Sempetmber in the past 2017 on the grounds that they still doubt the legality of MR vaccine because there is actually no fatwa specifically about the halal vaccine used in MR vaccination. One of them is Islamic Boarding School (Pesantren ) which is cared for by KH. Muhlisul Amal Jurang Village, Bandongan District, Magelang Regency. Muhlisul flatly refused vaccination to his students for this reason even though he claimed to know through news on the Internet. Mukhlisul Amal and some of his communities reject the implementation of vaccinations to his students for religious and theological reasons. This reason is commonly used by religious communities in general

The doubts of some of the Pesantren caregivers in Magelang can be understood because in reality there is no MUI Fatwa specifically explaining the Measles Rubella (MR) vaccination law. Kholil Nafis as one of the MUI central administrators said that the MUI had not issued a fatwa related to the legal use of vaccines in Measles Rubella vaccination because it had not made observations related to the vaccine. That is because the Ministry of Health of the Republic of Indonesia has not submitted a fatwa request to MUI regarding the vaccine's halal status until the implementation of MR vaccination in 2017. He said that until now ${ }^{3}$ the MR vaccine had never been submitted to MUI for halal certification.

According to the researcher, this phenomenon is a unique and disturbing

${ }^{1}$ Daiki Kanbayashi, et all. 2017. "Rubella Virus Genotype 1E in Travelers Returning to Japan from Indonesia, 2017”, PMC Journal, 2018 Sep.

2 Adib Rifqi Setiawan, et al. 2016. "A Short Description of Pondok Pesantren", Nlobatnis Research Society $(\Lambda R S)$, November 21.

3This news was published on August 2, 2018. 
problem. Therefore this issue is important and interesting to be discussed and analyzed in order to determine the response of the Pesantren community to the implementation of Measles Rubella vaccination that has been carried out in 2017. Besides, it is also important and urgent to know the effect of the fatwa on the mindset of the Pesantren community. with the halal law of MR vaccination vaccine specifically and in general concerning measles vaccine, and so on.

This article will focus on discussing three things: first, the response of the Pesantren community in Magelang to the Measles Rubella (MR) vaccination law in 2017. Second, the factors that influence the acceptance or rejection of the Pesantren community in Magelang towards the Measles Rubella (MR) vaccination law in 2017. Third, the influence of the MUI Fatwa no. 4 of 2016 on the mindset of the Pesantren community in Magelang Regency. The author used a sociology approach. Data obtained through observation, interview and literature study. The author used deductive-inductive methods and critical reflection to analyze the data.

\section{B. Vaccination on Law Perspectives}

In terminology, vaccination is a way to actively increase a person's immunity to an antigen ${ }^{4}$, so that if later he is infected with a similar antigen does not occur disease ${ }^{5}$. As a health program, vaccination is an infectious disease prevention program that is implemented by providing vaccines so that people are immune/ immune or resistant to the disease. The vaccination program starts at the age of the baby until entering school age. 6 Through this program, children will be given a vaccine that contains certain types of bacteria or viruses that have been weakened or deactivated to stimulate the immune system and form antibodies in their bodies. ${ }^{7}$ Antibodies that are formed after vaccination will be very useful to protect the body from bacterial and viral attacks in the future. ${ }^{8}$

Until now, vaccination or vaccination is the best and most effective preventive effort in health efforts. In the world of medicine, vaccination or vaccination is the most successful technology as the best contribution of knowledge in the world. The main purpose of vaccination is the realization of immunity or immunity to the threat of disease. ${ }^{9}$

In some European countries, America and even in Asia it has been proven that vaccination can maintain immunity in children for eight to eighteen years after they are

4 Groom et al," Immunization Information Systems to Increase Vaccination Rates A Community Guide Systematic Review", Journal of Public Health Management and Practice, (May/June 2015-Volume 2 -Issue 3).

5 Basri, Carmelia dkk.. 2009. Pelatihan Imunisasi Dasar Bagi Pelaksana Imunisasi di UPK Swasta, (Jakarta: Departemen Kesehatan RI); 14.

${ }^{6}$ Funk, Cary. 2017. Mixed Messages about Public Trust in Science. Issues in Science and Technology Journal Vol. 34, No. 1 (FALL 2017); 86-88.

7 Oltean, Hanna N., Kathryn H. Lofy, Marcia J. Goldoft and Charla A. DeBolt, "Human Papillomavirus Vaccination in Washington State: Estimated Coverage and Missed Opportunities, 2006-2013", Public Health Reports (1974-), Vol. 131, No. 3 (MAY/JUNE 2016); 474482.

8 Rajan Kumar Pandey, at all. 2019. Vaccination and Immunization Strategies to Design Aedes Aegypti Salivary Protein Based Subunit Vaccine Tackling Flavivirus Infection, International Journal of Biological Macromolecules, Volume 122.

9 Sri Rezeki S. Hadinegoro., dkk. 2011. Pedoman Imunisasi di Indonesia, Edisi 4, Cet. I, (Jakarta: Badan Penerbit Ikatan Dokter Anak Indonesia), 6. 


\section{immunized. ${ }^{10}$}

In Indonesia, vaccination programs have been started since the 19th century to eradicate smallpox on the island of Java. The last case of smallpox in Indonesia was discovered in 1972 and in 1974 Indonesia was officially declared a free of smallpox countries. Between 1977 and 1980 BCG, DPT and TT vaccinations were introduced respectively to provide immunity against $\mathrm{TB}$, pediatric diphtheria, pertussis and tetanus neonatorum diseases. In 1981 and 1982, polio and measles antigens were introduced, starting in 55 sub-districts and known as the Sub-district Vaccination Program Development. 11

In 2017 the Indonesian government through the Ministry of Health of the Republic of Indonesia conducted a Measles Rubella (MR) vaccination program to prevent measles and rubella in children and adults. The two diseases need to be addressed immediately through the vaccination program because they can cause miscarriage (abortion) for pregnant women, even to the point of death, the target is the general public, school students, madrasah, and Pesantren, said dr. Ma'sumah The head of the Bandongan Community Health Center, District Magelang.

In terms of health, vaccination means the administration of vaccines to prevent the occurrence of certain diseases ${ }^{12}$ As quoted from the book entitled Controversy on Vaccination owned by dr. Siti Aisyah Ismail, et al, said that aside from the benefits, both medical and financial, vaccination actually does not contradict Islamic religious norms because basically Islam asks its followers to take care of themselves from diseases before they occur. The Messenger of Allah said, "Whoever eats seven ajwah dates, he will be spared that day from poison and magic," (Hadith narrated by AlBukhari).

The Hadith suggests that making preventive efforts to avoid disease is recommended. K. Aminudin Yakub, MA as one of the members of the Indonesian Ulama Council (MUI) has an opinion that at the time of the Prophet, a vaccine had not yet been found ${ }^{13}$. He said that in the level of Islamic law, there were exceptions where unclean or unclean vaccines were permitted, namely al-emergency, al-hajat and there was information from medical staff or competent experts that there was no halal vaccine. If this exclusion condition occurs, then the law will change from haram to halal. 14

The Indonesian Ulama Council which allows the use of MR (Measles-Rubella) vaccine despite containing pigs, has become a public conversation, especially among the elderly. The Indonesian Ulama Council has actually asserted that the Measles Rubella (MR) vaccine produced by the Serum Institute of India (SII) used for vaccination in Indonesia in the 2017 vaccination policy program is haram because it

10 Groom et al," Immunization Information Systems to Increase Vaccination Rates A Community Guide Systematic Review", ( May/June 2015-Volume 2 -Issue 3); 227-248.

11 Holipah at al, 2018. Determinants of immunization status among 12- to 23-month-old children in Indonesia (2008-2013): a multilevel analysis, BMC Public Health, volume 18, Article number: 288.

12 Kroger, Andrew T., Ciro V. Sumaya, Larry K. Pickering and William L. Atkinson, 2017. General Recommendations on Immunization: Recommendations of the Advisory Committee on Immunization Practices (ACIP). Morbidity and Mortality Weekly Report: Recommendations and Reports, Vol. 60, No. 2 (January 28, 2011); 1-60.

13 Agung Taufiqur Rokhman Syiroj, at al. 2019. " Exploring Parents' Reasons for Incomplete Childhood Immunisation in Indonesia", Vaccine, Volume 37, Issue 43, (8 October 2019); 6486-6493.

$$
14 \text { Ibid., }
$$


clearly contains pig enzyme elements. The affirmation was stated in Fatwa of The Indonesian Ulama Council number 33 of 2018.15

However, in reality the Indonesian Ulama Council allows its use for several reasons, namely first, the existence of a forced condition. Secondly, besides that, also because there has not been found a halal and holy MR vaccine. Third, there is information from competent and trusted experts about the dangers posed by not being immunized. Fourth, there is no halal vaccine yet. Such is the statement of the Indonesian Ulama Council in its release which was signed by the Chairman of the MUI Fatwa Commission, Hasanuddin, on Monday, August 20th, 2018

Based on the description above shows that the implementation of MR vaccination that has been carried out in 2017 has preceded the emergence of the fatwa of Indonesian Ulama Council (MUI). This is what actually raises the polemic of pros and cons in the community, including among Pesantren about the MR vaccination law. If the fatwa arises before the implementation of the vaccination course, it would be able to minimize the rejection of some of the community targeted and targeted by the government program.

\section{Vaccination in the Religious Perspectives}

1. Islamic Perspective

According to Islam, avoiding danger takes precedence over bringing benefits because it actually avoids danger in its essence is the goodness itself. Islam as a religion that emphasizes goodness for life always approves all activities aimed at goodness including vaccination. But at the level of implementation there are pros and cons of the Muslim community regarding the implementation of vaccination. it is caused by differences in their understanding and perspective. Some people agree with vaccination. They understand that vaccination is a preventive effort to avoid disease. They also understand that following the vaccination program is a form of obedience to the government that has programmed vaccination in order to protect the health of its people. As for the people who refuse the implementation of vaccination, they generally argue that vaccination is haram because the manufacturing process involves elements of pig enzymes. ${ }^{16}$

Differences in views with the justification of religion, which resulted in the implementation of vaccination in any part of the country can not run one hundred percent of the desired target. The Ministry of Health stated, the average coverage of rubella measles vaccination throughout Indonesia reached 87.33 percent. The results were monitored through the results of the 2017 vaccination campaign in Java and 2018 outside Java.

The involvement of religious leaders is very important to improve vaccination coverage. According to Islam, vaccination is part of the deed that is not detached from the religious norms that are the norm associated with halal food. Therefore, some people reject vaccination with the reason that the material injected into the body is not halal (forbidden) because the manufacturing process allegedly involves elements of pig

15 Edi Krisharyanto, Endang Retnowati, Noor Tri Hastuti. 2019. "Regulation and Provisions for Supervision of Halal Products in Indonesia", Journal of Legal, Ethical and Regulatory Issues, Vol: 22 Issue: 1.

16 Muhammad Mustaqim Mohd Zarif, at. al, "The Use of Forbidden Materials in Medicinal Products: An Islamic Perspective", Middle-East Journal of Scientific Research, (05 October, 2013). 
enzymes. ${ }^{17}$

In medical sciences rubella or the said of German measles is a disease caused by viruses. The spread through direct contact between sufferers with the environment or through the air. This disease often occurs in children. When a child has contracted the disease caused by the virus rubella then it is not treatable. The medicines provided can only reduce the symptoms.

Based on medical considerations as such, it can be understood that regardless of the material used for vaccination is suspected to contain pig elements, but the danger that may be suffered by children as a result of not being immunized very much worry. Thus there are two sides that need to be considered in the implementation of vaccination that consumes unclean food on one side and avoid the harm on the other side. If this happens then avoid the harm, namely the danger of illness that will be suffered by children because it is not immunized to them should take precedence over the vaccination by reason of not consuming the unclean food which is still a suspect. Thus, Islam allows vaccination because it can avoid harm. With this reasoning it is obvious that choosing approval will be vaccination is part of choosing a lighter risk.

2. Cristianity Perspective

Vaccination in a Catholic religious perspective is highly recommended because vaccination is one of the modern ways to prevent the infection from being caused by viruses that are very dangerous. Synod's last document states: "Vaccination is a powerful tool for the prevention of highly hazardous infectious diseases. In some cases, there may be complications of diseases caused by vaccination or vaccination in children. The Orthodox Church in Russia expressly rejects the anti-vaccination campaign and forbades the distribution of anti-vaccination literature and audio-video material in its monasteries and temples. ${ }^{18}$

In contrast, Protestants or Christians provide looseness to his People in vaccinations or vaccinations. There is no single authority in determining the legal status of human action included vaccinations and vaccinations. Lot of man has responsibility for his deeds. For parents who refuse to immunize or vaccinate in their children, it is argued that religion should not be used to justify it because the vaccination is actually a prohibition of God. As for parents who receive their children vaccinated or immunized, it is argued that it is the grace of God in order to avoid their children from threats of harmful diseases. ${ }^{19}$

The two arguments, both pro and contra, towards vaccination appear to have similarities with the arguments of the Pesantren community as a representation of the Muslim community in Magelang and in Indonesia in general. Those who have rejected their students being immunized argue that vaccination is prohibited by sharia because the vaccine production process involves the element of a pig enzyme. Whereas for those who receive their students immunized, the argument is that the danger of disease in children who are not immunized is more severe than the danger of using illicit objects. Vaccination is an urgent or emergency need that can allow it to crash.

17 J. C. Costa, A. M. Weber, G. I. Darmstadt et al. 2019. "Religious affiliation and immunization coverage in 15 countriesin Sub-Saharan Africa", Vaccine journal, https://doi.org/10.1016/j.vaccine.2019.11.024.

${ }_{18}$ Geppe and A.B. Malachova . 2010. Vaccination for Children, (Moscow: Russian Orthodox Church); 40.

19 Wilhelmina LM Rujis, et.all. 2012. How Healthcare Professionals Respond to Parents with Religious Objections to Vaccination: A Qualitative Study, BMC Health Service Research, vol 12, (2012); 212-231. 


\section{Buddhist Perspective}

In general, Buddhist teachings are rather conservative in terms of using all forms of life to make vaccines. Modern Buddhists generally want to use vaccines to protect their health. But according to the essence of Buddhism, vaccines are still being debated when vaccines are not to protect life, meaning that the core of Buddhism is protecting life. Therefore, basically Buddhism prohibits vaccines because it is part of killing the lives of animals whose enzymes are used to produce vaccines. The first of the Ten Precepts is the "prohibition on eliminating life. Thus Buddhism basically forbids all actions that will lead to the destruction of potential life. Therefore, Buddhism teaches its followers to treat all lives well. ${ }^{20}$ On the other hand, Buddhist biomedical researchers believe that the goal of biomedical research is to save rather than sacrifice lives. Buddhist biomedical researchers conduct experiments for the love of life, for example, they experiment with tissue donations to help people survive and protect their lives. thus it can be understood that vaccination even though the process involves killing the lives of pigs to take enzymes as a catalyst in the vaccine production process does not mean that it has done bad karma. The modern view of Buddhism will emphasize the importance of saving lives rather than taking life. In general, Buddhist teachings are rather conservative in terms of using all forms of life to make vaccines. ${ }^{21}$

4. Hindu and Jewish Perspective

In India, researchers sought to identify the culture and sociodemographic factors that influence vaccination, using data from 108,057 children. The survey results showed that $57 \%$ of Indian children aged between 1 and 3 were fully vaccinated, 31\% were not decalcinated, and only $12 \%$ were not vaccinated. The results of his analysis showed that more Muslim children were not vaccinated compared to Hindu children. Children born in Buddhism, Jain Families, Jews or Zoroastrians are less likely to be vaccinated. So do children born in Hinduism, Christianity, and Sikh families. ${ }^{22}$

The results of the study indicate that Hinduism accepts vaccinations and vaccinations on the grounds of protecting health and considers it important to ensure the safety of children from contracting the disease due to being not immunized. They do not question the process of producing a vaccine that is injected into a child's body in order to gain immunity against diseases that may be caused.

Likewise the Jewish religion receives vaccinations because it is part of the effort to preserve the next generation of human beings. Even though Jewish theology does not explicitly emphasize this, vaccination is not known explicitly in the Bible and the Talmud, but in the Bible and Talmud recognize and encourage efforts to maintain health and life, especially cleanliness. In Jewish theology it is said that God created humans not only for physical purposes, but also for mental and spiritual imagery. When God commands humanity to "bear fruit and multiply," the way to do God's command is left entirely to humans. Therefore maintaining the health and safety of generations through rational efforts becomes a necessity. one such effort is to immunize children in order to avoid disease. Thus doing vaccination to ensure the health of children as the next generation of human life is an act of carrying out God's

${ }^{20}$ RC, Chen. 2002. Learning Medicine and Learning Buddhism (In Chinese), (Taipei: Hui-chi);

27.

21 Ibid,

${ }_{22}$ N, Shrivastwa, Gillespie BW, Kolenic GE, Lepkowski JM, Boulton ML., Predictors of Vaccination in India for Children Aged 12-36 Months. Am J Prev Med (18 Aug 2015),. 
commands. 23

\section{NGO's Responses to Vaccination}

Talking about the real response is inseparable from two things namely negative responses and positive responses. Response is an activity of an organism to the reality of the situation and environmental conditions. Therefore the response is not merely a positive movement but also negative. ${ }^{24}$ In general, the response can be interpreted as the result or impression obtained from someone's observations about the subject, events or relationships from the environment obtained by summarizing information and interpreting messages. ${ }^{25}$

According to the law of causality, a response can be formed if the causes have been fulfilled. In the initial process the individual organizes responses not only from stimulants caused by the situation and conditions around. But mystic situations and individual conditions also contribute to the emergence of responses. ${ }^{26}$

Thus the circumstances around which an individual will respond depends on the stimulus and the individual's situation. The process of the emergence of a stimulus response will get an election and the individual will depend on two factors, namely internal factors and external factors. ${ }^{27}$ (Bram Geurkink et. al, 2020: 247 -267) The internal factor is someone's mystical situation. While the external factor is the environment.

\section{E. Implementation of Vaccinations in Islamic Boarding Schools (Pesantren) \\ 1. Vaccination Recipients}

Based on the results of data collection through interviews found two different attitudes of the Islamic boarding school community, namely the attitude of rejection and acceptance. Some of them received the vaccination program because they thought the program was for health. According to dr. Hj. Masumah the head of the Bandongan Community Health Center, there are 7 (seven) Islamic Boarding Schools in the Bandongan sub-district who explicitly accept the vaccination program. One of them is the Pesantren Ma'ahidul Irfan who is raised by KH. Aliyul Munif Qostholani, Lc. (Interview with dr. Hj. Masumah Head of the Bandongan Health Center)

Aliyyul Munif Qostholani said emphatically that the legal vaccination is halal / permissible for health reasons and to reject mafsadah that may arise namely rubella or measles which can result in death. (Interview with K.H. Aliyyul Munif Qostholani, Lc) The caregiver of the Pesantren Ma'ahidul Irfan is famous as one of the pious and wise scholars, his mindset is not narrow. In his community, besides being a caregiver, he is also a Rois Syuriah (chief of syuriah) Branch Representative Assembly of the Nahdlatul Ulama Bandongan District. This opinion would be appropriate in accordance with the rules of fiqhiyya "which brings danger removed. The purpose of this rule is that

${ }^{23}$ Grabenstein, John D. 2013. "What the World's Religions Teach, Applied to Vaccines and Immune Globulins", Vaccine Journal.; 2011-2023.

${ }^{24}$ Robert Bartlett, 2017. "Response", Church History 85:4 (December 2016); 810-813.

25 Stanley K Diamenu, 2017. "Closing the Immunization Gaps through Community Empowerment and Private Sector Collaboration", International Jounal of Vaccines and Immunization.

${ }^{26}$ Kutluğhan Soyubo, 2019. "In Search of Perfection: Neo-spiritualism, Islamic Mysticism, and Secularism in Turkey", Modern Intellectual History, (2019); 1-25.

${ }^{27}$ Geurkink, Andrej Zaslove at al., "Populist Attitudes, Political Trust, and External Political Efficacy: Old Wine in New Bottles?" Political Studies, Vol. 68(1), (2020); 247-267. 
eliminating harm or danger takes precedence over others. ${ }^{28}$ Even if the MR vaccine is forbidden, it is forbidden but if you see information from expert doctors that the danger of illness and even death may be caused by not having vaccination, the need for vaccination can be positioned in an emergency position that can allow prohibitions according to the rule "The evil allows the forbidden.

MR vaccination law can be compared with meningitis and bird flu vaccinations which were initially allowed for emergency reasons and then obtained halal certification based on MUI (Indonesia Ulama Council) Fatwa Number. 4 of 2016. Both laws are equalized because of the similarity of illat al-hukm (legal reasons) namely the existence of an emergency element and an element of rejecting mafsadah (damage) which is the emergence of a disease that can result in death. Even for him, if vaccination is an effort to maintain health and avoid death, then the law is mandatory because it includes caring for the soul and caring for the soul is one of the five human rights that must be maintained. This opinion is based on a fighiyya principle "needs to be placed in an emergency position" ${ }^{29}$

Just like Saiful's opinion as one of the administrators of the Al-Asnawi boarding school, Kyai Maimun Asmu'i caregiver of the Al-Ikhlas boarding school in Mantusari Village agreed with vaccination. He argued that the vaccination program launched by the government is actually for the benefit of the people and a form of government alignments for the people so that they can live healthy lives free from diseases that can be harmful to life. He believes that the program is good. Therefore he allowed his students to be immunized. (Interview with Bandongan Vaccination Officer)

It is said that in the context of vaccination as an effort to obtain health and prevent disease in a preventive manner is actually part of mu 'amalah which according to the basic rules is permitted while the alleged pig element in MR vaccine still needs proof. Therefore, if these elements are not or have not been proven clearly, then there is actually no obstacle to follow MR vaccination. The next recipient of vaccination from the Pesantren community was the Sabilul Muhsinin Islamic boarding school of Kiai Mudzakkir. I heard information about the possibility of a child getting measles and rubella if they have not been immunized measles rubella (MR).

Kiai Muqoddas as caregiver of Sirojul Aulad Islamic boarding school also believes that illness is something that must be sought to be lost. So avoiding disease, including avoiding harm. Based on the fiqhiyyah principle that mudarat must be eliminated, students in this Pesantren are allowed to participate in the vaccination program. Besides that, the reasons for following the government's recommendations that are legal and not against the Shari'a are citizens' obligations.

From the information and information referred to above, it can be seen that Pesantren (Islamic Bourding School) residents welcomed with appreciation for the implementation of measles and rubella vaccination held in 2017. All the Pesantren receiving the vaccination are active as board members of the Nahdlatul Ulama, as the largest organization in the subdistrict level of Indonesia. This shows the principle with the principle of moderation (tawassuthiyyah) as one of the principles of NU movement (harakah nahdliyyah) and appreciation with legitimate government policies, they can receive vaccinations.

They believe that the government's policy has considered the benefit of Indonesian citizens to avoid measles and rubella caused by viruses that can interfere

28 A. Basiq Djalil, 2014. Ilmu Ushul Fiqih (Satu dan Dua), Cet. Ke-2, (Jakarta: Kencana Prenada Media Group); 138.

${ }^{29} \mathrm{Ibid}, 140$. 
with immunity as a result of not doing vaccinations. This is in accordance with the rules "The leader's policy towards his people depends on goodness (mashlahah)". 30

In line with the Pesantren mentioned above, the modern Pesantren under the care of Ahmad Najib and the Pesantren Pabelan 2 under the care of Ustadz Hanan also received their students immunized. Their reason is because MR vaccination even though it has not received halal certification from the MUI as a formal institution formed by the government specifically, but seeing the urgent needs and indeed has been programmed by the government, then it can be done.

From the explanations and reasons of the Pesantren caregivers who received their students for the vaccination, it can be understood that their acceptance actually leads to appreciative and accommodative attitudes towards the policies that have been made by the government.

2. Vaccination Repellent

In addition to the many Pesantren that have received measles and rubella vaccinations, there are still a number of Pesantren that expressly uncompromisingly reject these vaccinations and even other types of vaccinations as a whole. The rejection was related to the information they received from the electronic media that had been read and the distrust of socialization from the puskesmas regarding vaccination, and some were even suspected of refusing to be asked to accept as targets for program socialization.

As for those who reject the vaccination program, there is 1 (one) Pesantren in the working area of the Bandongan Community Health Center. The Pesantren is named Darut Tauhid 2 which is located in the village of Jurang. The caregiver - to the knowledge of the researcher - was named KH. Muhlisul A'mal, an alumnus of Darut Tauhid Islamic Boarding School, Kedungsari Purworejo, led by KH. Thoifur Mawardi. $\mathrm{KH}$. Thoifur Mawardi himself is an Pesantren alumnus of al-Habib Muhammad Alawi al-Maliki al-Makki Mecca in Saudi Arabia. This cleric has a strict and textual view when it comes to halal and haram law. He always does not compromise things that smell unclean like when there were differences of opinion about the prohibition of smoking. He agreed with the law because he himself did not smoke even though he invited other kiai from his community to smoke when he thought that the law of smoking was not haram but only makruh.

Based on the observations of the researcher in each discussion both in the Bahtsul Masail NU forum at the district level and outside the forum, KH. Muhlisul Amal (can I call Mr. Lis) his mindset tends to be literal and rigid. One proof of that rigidity is not willing to accept and meet the arrival of female guests, including $\mathrm{dr}$. Hj. Ma'sumah as the head of the Puskesmas that is dominating his Pesantren, even though it has been said that his arrival is in the name of official service. (Interview with dr. Ma'sumah)

Muhlisul argued that he and all his students did not want to receive the full vaccination program on religious grounds, namely that vaccination was illegitimate because it was strongly suspected that the manufacturing process contained pig enzyme. In addition to MR vaccination, he refused on the grounds that there was no halal certification from the Indonesian Ulama Council (MUI) on its vaccine products. Thus dr. Ma'sumah said it is also confirmed by Muhlisul's statement. He did not agree that if the MR vaccination law was equated with the meningitis and bird flu vaccination laws given to prospective pilgrims from Indonesia. That is because in the vaccination of meningitis and avian influenza, it has clearly been claimed to be halal by

30 Jalaluddin Abdurrahman Assuyuti. 1983. al-Asybah wa an-Nadhāir, (Beirut: Dar alKutub al-Ilmiyah); 142. 
MUI through Fatwa Number 4 of 2016 and is an unavoidable need for pilgrims from Indonesia, while this is not the case with MR vaccination. (Interview with K.H. Muhlisul A'mal)

In Kaliangkrik District the majority of Pesantren receive vaccination programs so there are no significant obstacles in implementing MR vaccination. there is only one Pesantren that clearly rejects it, the Pesantren Luqmanul Hakim. This Pesantren is affiliated with the Prosperous Justice Party. Ustadz Sarjono as a board (semacem caregiver) of the Pesantren rejects vaccination in diplomatic language. He is in the name of walisantri who refuses vaccination. In discordant language, he said that his Pesantren did not reject vaccination but also did not advocate, it was the guardians of the student (santri) who refused. (Interview with Ust. Sarjono)

Furthermore, in reality the Pesantren students managed by Sarjono did not want to be immunized. Although initially diplomaticized that he did not refuse but did not advocate, but he was among those who argued that the legal vaccination is not halal for two reasons. First, the vaccination for Sarjono is haraam because based on information received from electronic media as well as print and social media, the vaccine used in the vaccination process involves making pig enzymes. Therefore punished with the same law using the pig enzyme, which is haram. The law still applies even in emergencies. The second reason, is, because there is no halal certification from Majlis Ulama Indonesia against the vaccine used in MR vaccination. He did not agree if the MR vaccination law was compared to the meningitis and bird flu vaccination laws which had received halal certification from MUI through MUI Fatwa No. 4 of 2016. For Sarjono there is no word emergency in vaccination because actually treatment is legal (jawaz) not mandatory.

In line with Sarjono, Ust. M. Zaidan who is also one of the administrators of the Luqmanul Hakim Foundation. He also diplomatically said he did not accept but also did not reject MR vaccination, but in reality he said that the MR vaccination law cannot be compared to the vaccination law for meningitis and bird flu. This means that he thinks MR vaccination is forbidden while vaccination for meningitis and halal bird flu. This can be understood from his statement which says that he did not include the Luqmanul Hakim Islamic boarding school students on the grounds that there was no halal certification from the MUI.

From the Sawangan community health center, information was obtained that in the implementation of MR Vaccination, there were some who refused to be immunized, one of which was obtained from Sawangan's puskesmas, some who rejected it, namely the modern boarding school Gontor 6, the Zaid bin Tsabit Integrated Islamic Elementary School, headed by Ustadz Kusaeri , Islamic boarding school Umar bin Khattab Grabag, boarding school Umar Bin Khattab Srumbung who was raised by Ustadz Hanip Sunaryo.

All of them except the caregiver of the modern Islamic boarding school Gontor, argued that vaccination was haraam because the process of making the injected vaccine was mixed with pig enzymes. The reason used by the caregivers of the modern Gontor 6 Islamic Buording School is it was not instructed by the central Pesantren or its parent, the Modern Pesantren Darus Salam Gontor, said Ustadz Sunanto, one of the administrators and teachers at the Pesantren on July 5, 2018.

The Islamic boarding schools of Umar Bin Khattab Srumbung who were taken care of by Ustadz Hanip Sunaryo said that they refused but seemed half-hearted because of their caregiver's admission that their foster children namely students were not included in vaccinations on the grounds that they were teenagers even though many of their students were still sitting in classes 13 and 14 . which is less than 15 years 
old. ${ }^{31}$

Findings from the Grabag 1 Public Health Center reported that there were 2 Pesantren -based schools that refused some of their students to be immunized. The two institutions are SDIT At-Taqwa with 21 children out of 422 children refusing to be immunized. Then At-Taqwa Middle School there were 105 children out of 248 children refused to be immunized. The two institutions have a textual-literal pattern of religious understanding. They tend to be less accommodating of government policies related to halal and haram law.

Understanding some of the opinions of Pesantren caregivers appears because they believe more information from the media about the prohibition of vaccination because the process of making the vaccine used in vaccination involves pig enzymes. While the socialization from the government in this case is the Magelang District Health Office, it seems that it is still not optimal so that it has not been able to provide adequate explanations to be accepted by Pesantren who refused their students to be immunized by MR in 2017 last year. Based on this data, according to researchers, it can be seen that all Pesantren that refuse vaccination are Pesantren that fall into the exclusive category and some are right-leaning.

\section{F. Conclusion}

Islamic boarding schools (Pesantren ) with ASWAJA orientation accept and allow MR vaccination for the following reasons; First, MR vaccination is not different from other vaccinations such as measles, polio, etc. which have received halal certification from Indonesian Ulama Council (FATWA MUI NO. 4 of 2016), because both are carried out in order to prevent the incentive to contract certain diseases due to not being carried out vaccination. Secondly, vaccination is a preventive effort to prevent disease as a madlarat recommended by religion.

Whereas the Pesantren that are right-leaning, exclusive and tend to be literaltextual like the Pesantren Luqmanul Hakim, the Salafi Pesantren in Mungkid are managed by Bp. Sujadi and Darut Tauhid 2 Pesantren from KH. Muhlisul Amal refused MR vaccination for the following reasons; First, MR vaccination is haraam because it is suspected to contain lard in the process of making a vaccine that is injected into the human body at the time of vaccination. Second, there is no Halal Fatwa from MUI related to the MR vaccine. Third, the MR vaccination law cannot be compared to other vaccination laws other than those that have been declared halal by the MUI.

The factors influencing acceptance of MR vaccination law are as follows; First, vaccination as a preventive effort is not prohibited but is recommended by religion. Second, the allegation of the presence of pig enzyme is not yet legally and convincingly proven. Third, obeying the government which is legally obligatory unless the order is clearly immoral (haram).

The factors that influence the rejection of MR vaccination law are as follows; First, it is strongly suspected that the vaccine used in MR vaccination is mixed with pig enzymes. Therefore the law is haram. Secondly, there has been no MUI fatwa specifically specifying the halal vaccine used in MR vaccination. Third, the need to avoid danger has not reached the level of emergency because the danger arising from not participating in vaccination is suspected, because sickness and health are God's destiny.

The MUI Fatwa No. 4 of 2016 has an influence on the mindset of the Pesantren

${ }^{31}$ Interview with Ustadz Hanip Sunaryo, July 7, 2018. 
community in Magelang which has ASWAJA-oriented and substantive mindset. They postulate that fatwas are part of fiqh that may be followed. Although the MUI fatwa was made for cases that apply specifically, but because there is a clause in which the meaning can be expanded to reach other cases that have the same legal motivation, the fatwa is religiously valid for use as an argument or basis for the MR vaccination. MUI Fatwa No. 4 of 2016 does not affect the mindset of the Pesantren community in Magelang which is right-leaning, exclusive and textualist-literalist. They consider that the fatwa is an alternative non-binding. Therefore, everyone can determine based on their knowledge and experience. They may submit to the fatwa and vice versa they may also ignore it.

\section{G. Acknowledgments}

This paper and the research behind it would not have been possible without the exceptional support of my colleagues. Their enthusiasm, knowledge and exacting attention to detail have been an inspiration and kept my work on track from my first word to the final draft of this paper.

\section{H. Author Contributions Statement}

JA and AAR, my colleagues at FSH Universitas Islam Negeri Walisongo Semarang, have also looked over my transcriptions and answered with unfailing patience numerous questions about data and the language. AM from Marmara Üniversitesi İstanbul Turki, not only provided some advices of the manuscript overnight, but also provides some essential critics on this paper[.]

\section{REFERENCES}

Bartlett, Robert. 2017. "Response", Church History 85:4 December 2016, American: American Society of Church History,

Basri, Carmelia dkk.. 2009. Pelatihan Imunisasi Dasar Bagi Pelaksana Imunisasi di UPK Swasta, Jakarta: Departemen Kesehatan RI.

Costa, J. C., A. M. Weber, G. I. Darmstadt et al. 2019. “Religious affiliation and vaccination coverage in 15 countriesin Sub-Saharan Africa", Vaccine journal, https://doi.org/10.1016/j.vaccine.2019.11.024

Diamenu, Stanley K. 2017. "Closing the Vaccination Gaps through Community Empowerment and Private Sector Collaboration", International Jounal of Vaccines and Vaccination,

Funk, Cary. 2017. Mixed Messages about Public Trust in Science. Issues in Science and Technology Journal Vol. 34, No. 1 (FALL 2017), Texas: University of Texas at Dallas.

Geppe and A.B. Malachova . 2010. Vaccination for Children, Moscow: Russian Orthodoxy Church.

Grabenstein, John D. 2013. “What the World's Religions Teach, Applied to Vaccines and Immune Globulins", Vaccine Journal.

Groom et. al,. 2015. Vaccination Information Systems to Increase Vaccination Rates A Community Guide Systematic Review. Journal of Public Health Management and Practice: May/June 2015 - Volume 21 - Issue 3

Hidayatullah, Tetrawindu A. 2016. “Explanatory Study of Health Policy Agenda Setting in Indonesian Immunization Policy for Religious Anti-vaccinatio", Research dissertation, South Australia: Flinders University. 
Holipah at al, 2018. Determinants of vaccination status among 12- to 23-month-old children in Indonesia (2008-2013): a multilevel analysis, BMC Public Health, volume 18, Article number: 288.

Kanbayashi, Daiki et all.. 2017. "Rubella Virus Genotype 1E in Travelers Returning to Japan from Indonesia, 2017", PMC Journal, 2018 Sep.

Krisharyanto, Edi, Endang Retnowati, Noor Tri Hastuti. 2019. "Regulation and Provisions for Supervision of Halal Products in Indonesia", Journal of Legal, Ethical and Regulatory Issues, Vol: 22 Issue: 1.

Kroger, Andrew T., Ciro V. Sumaya, Larry K. Pickering and William L. Atkinson, 2017. General Recommendations on Vaccination: Recommendations of the Advisory Committee on Vaccination Practices (ACIP). Morbidity and Mortality Weekly Report: Recommendations and Reports, Vol. 60, No. 2 (January 28, 2011), Published by: Centers for Disease Control \& Prevention (CDC)

Lodhi, Fahad Saqib, Esmaeil Khedmati Morasae \& Reza Majdzadeh. 2018. Differential achievements in childhood vaccination across geographical regions of Pakistan: analysis of wealth-related inequality. International Journal for Equity in Health, volume 17, Article number: 122 (2018)

MC, Tai. 2008. The Way Of Asian Bioethics, Taipei: Princeton International Publishing Co. Ltd.

N, Shrivastwa, Gillespie BW, Kolenic GE, Lepkowski JM, Boulton ML., Predictors of Vaccination in India for Children Aged 12-36 Months. Am J Prev Med 18 Aug 2015,

Oltean, Hanna N., Kathryn H. Lofy, Marcia J. Goldoft and Charla A. DeBolt,"Human Papillomavirus Vaccination in Washington State: Estimated Coverage and Missed Opportunities, 2006-2013", Public Health Reports (1974-), Vol. 131, No. 3 (MAY/JUNE 2016), Published by: Sage Publications, Inc.

Pandey, Rajan Kumar at all. 2019. Vaccination and Vaccination Strategies to Design Aedes Aegypti Salivary Protein Based Subunit Vaccine Tackling Flavivirus Infection, International Journal of Biological Macromolecules, Volume 122.

RC, Chen. 2002. Learning Medicine and Learning Buddhism (In Chinese), Taipei: Hui-chi..

Rujis, Wilhelmina LM et.all. 2012. How Healthcare Professionals Respond to Parents with Religious Objections to Vaccination: A Qualitative Study, BMC Health Service Research, vol 12, 2012.

Soyubo, Kutluğhan. 2019. "In Search of Perfection: Neo-spiritualism, Islamic Mysticism, and Secularism in Turkey", Modern Intellectual History, 2019.

Setiawan, Adib Rifqi et al. 2016. "A Short Description of Pondok Pesantren", Nlobatnis Research Society ( $\Lambda R S)$, November 21.

Assuyuti, Jalaluddin Abdurrahman. 1983. al-Asybah wa an-Nadhair, Beirut: Dar alKutub al-Ilmiyah.

Syiroj, Agung Taufiqur Rokhman at al. 2019. “ Exploring Parents' Reasons for Incomplete Childhood Vaccination in Indonesia", Vaccine, Volume 37, Issue 43, 8 October 2019.

Geurkink, Andrej Zaslove at al., "Populist Attitudes, Political Trust, and External Political Efficacy: Old Wine in New Bottles?" Political Studies, Vol. 68(1), 2020.

Groom et al," Vaccination Information Systems to Increase Vaccination Rates A Community Guide Systematic Review", Journal of Public Health Management and Practice: May/June 2015-Volume 2 -Issue 3.

Zarif, Muhammad Mustaqim Mohd at. al, "The Use of Forbidden Materials in Medicinal Products: An Islamic Perspective", Middle-East Journal of Scientific Research, 05-10, 2013. 